\title{
KOHESI DAN KOHERENSI DALAM NOVEL KKN DI DESA PENARI KARYA SIMPLEMAN DAN IMPLIKASINYA TERHADAP PEMBELAJARAN BAHASA INDONESIA DI SMA
}

\section{COHESION AND COHERENCE IN THE KKN NOVEL IN PENARI KARYA SIMPLEMAN VILLAGE AND ITS IMPLICATION FOR LEARNING INDONESIAN IN HIGH SCHOOL.}

\author{
${ }^{1}$ Ismi Ismawati, ${ }^{2}$ Sri Mulyati, ${ }^{3}$ Khusnul Khotimah \\ ${ }^{1,3}$ Universitas Pancasakti Tegal \\ 1ismiisma08@gmail.com, ${ }^{2}$ srimulyati03@gmail.com, $\underline{{ }^{3} \text { khusnulkups@gmail.com. }}$
}

\begin{abstract}
Abstrak
Kohesi dan koherensi memiliki peran penting dalam menulis karangan, baik yang akan menulis atau yang sudah menjadi sebuah karangan. Maka dari itu penelitian ini bertujuan untuk mengetahui penggunaan kohesi dan koherensi dalam novel KKN Di Desa Penari. Metode yang digunakan dalam penelitian ini yakni motode kualitatif. Data penelitian ini yakni kalimat yang terdapat jenis kohesi dan koherensi dalam novel KKN Di Desa Penari karya Simpleman. Teknik pengumpulan data menggunakan teknik baca dan teknik catat. Teknik penyajian hasil analisis menggunkan teknik informal. Teknik informal ialah teknik menyajikan data berupa kata-kata yang umum yang mudah dipahami oleh pembaca. Hasil penelitian ini yaitu terdapat jenis kohesi gramatikal, kohesi leksikal dan jenis koherensi. Kohesi gramatikal diantaranya: referensi, substitusi, elipsis, dan konjungsi. Penggunaan kohesi leksikal terdapat dua jenis yaitu, repetisi dan kolokasi. Penggunaan koherensi terdapat lima hubungan yaitu: hubungan penjumlahan, hubungan perturutan, hubungan perlawanan, hubungan sebab-akibat, dan hubungan waktu.
\end{abstract}

Kata Kunci: wacana, kohesi, koherensi.

\begin{abstract}
Cohesion and coherence have an important role in writing essays, whether they are going to write or have already become an essay. Therefore, this study aims to determine the use of cohesion and coherence in the novel KKN Di Desa Penari. The method used in this research is a qualitative method. The data of this research are sentences that contain the types of cohesion and coherence in the novel KKN Di Desa Penari by Simpleman. Data collection techniques used reading techniques and note taking techniques. The technique of presenting the results of the analysis uses informal techniques. Informal technique is a technique of presenting data in the form of common words that are easily understood by readers. The results of this study are there are types of grammatical cohesion, lexical cohesion and types of coherence. Grammatical cohesion includes: reference, substitution, ellipsis, and conjunction. There are two types of lexical cohesion, repetition and collocation. The use of coherence has five relationships, namely: addition relations, successive relationships, resistance relationships, cause-effect relationships, and time relationships.
\end{abstract}

Keywords: discourse, cohesion, coherence

\section{PENDAHULUAN}

Wacana merupakan sebuah peristiwa yang tersusun dalam keadaan rapi dan memiliki bentuk yang berupa perilaku linguistik (bahasa) atau yang lainnya Edmonson (Djajasudarma, 2006:2). Istilah wacana yang digunakan tidak harus pada suatu perbincangan atau tuturan saja, melainkan terdapat perundingan dimuka orang banyak, karangan, dan upaya formal 
misalnya tulisan pada bidang pengetahuan serta sandiwara atau lakon, sedangkan penjelasan wacana secara luas adalah cerita dari tuturan itu saling berkaitan (urutan kalimat-kalimat individual). Wacana bukan cuma terdiri dari ungkapan tuturan atau kalimat gramatikal dengan susunan secara sistematis Carslon (dalam Guntur Tarigan, 2009:22). Wacana menurut Djajasudarma (2006:3) wacana (discourse) merupakan kelompok bahasa yang terlengkap dalam hierarki gramatikal yaitu kelompok gramatikal yang tertinggi atau terbesar.

Wacana dalam hal ini diwujudkan pada ciptaan tulisan yang utuh dengan bentuk seperti buku, seri ensiklopedia, novel, dsb., kata, kalimat atau paragraf yang di dalamnya berisi pesan yang disampaikan secara utuh. Digambarkan pada sebuah bentuk dari wacana dapat melihatnya pada bagian tingkatan bahasanya, di mulai pada tingkatan yang terkecil (kata) yang di dalamnya berisi makna secara sempurna atau lengkap, bisa juga dilihat pada berita yang didukungnya, sedangkan pengertian wacana menurut KBBI edisi kelima ialah sekelompok bahasa terlengkap yang diwujudkan pada bentuk serangkaian tulisan atau karangan yang lengkap, misalnya pidato, khotbah, artikel, buku dan novel. Dari berbagai pengertian wacana di atas penulis bisa menyimpulkan bahwa wacana adalah rangkaian katakata yang di dalamnya disusun secara sistematis yang dijadikan sebuah kalimat, memiliki kohesi dan koherensi dengan jelas agar menjadi sebuah kalimat atau karangan yang utuh.

Di dalam novel, buku, artikel atau pidato akan lebih baik jika di dalamnya terdapat kohesi dan koherensi. Pengertian kohesi sendiri merupakan kecocokan ikatan pada unsur yang satu dengan unsur yang lainnya, sedangkan koherensi sendiri ialah hubungan pada kalimat yang satu dengan kalimat yang lain sehingga keseluruhan makna itu memiliki arti yang utuh dan jelas. Kohesi sendiri lebih merujuk pada bentuknya sedangkan koherensi merujuk pada sebuah maknanya.

Tujuan dari penelitian ini adalah Untuk mendeskripsikan kohesi dan koherensi yang ada pada novel KKN Di Desa Penari Karya Simpleman dan juga mendeskripsikan implikasi terhadap pembelajaran Bahasa Indonesia di SMA.

\section{METODE}

Metode yang digunakan dalam penelitian ini yakni motode kualitatif. Sumber data dalam penelitian ini adalah novel KKN Di Desa Penari Karya Simpleman. Teknik pengumpulan data pada penelitian ini memiliki dua teknik. Pertama teknik baca, teknik baca ialah teknik dasar metode simak yang dilakukan terhadap penulisan orang baik dibuku, majalah, koran maupun yang lainnya (Hermaji, 2016:156). Kedua teknik catat, teknik catat adalah cara mengambil data melalui penulisan yang ditulis dari hasil data yang telah disimak, dalam teknik catat ini dilakukan dengan cara ketika menerapkan metode simak, lalu data yang telah disimak dapat diambil dengan cara dicatat (Kesuma, 2007:45).

Teknik pada analisis data ini menggunakan metode agih. Metode agih ialah alat dari datanya berada di dalam sumber tersebut, data dari bahasa yang ada di dalamnya merupakan bagian kebahasaan yang kemudian data itu diteliti dalam penelitian ini Sudaryanto (dalam Kesuma, 2007:54). Kalau yang diteliti adalah satuan kebahasaan dalam bahasa Indonesia itu pula. 


\section{HASIL DAN PEMBAHASAN}

Hasil dari penelitian ini yang telah ditemukan pada novel KKN Di Desa Penari Karya Simpleman terdiri atas kohesi penanda gramatikal, kohesi leksikal, dan penanda koherensi. Kohesi gramatikal diantaranya meliputi referensi, substitusi, elipsis, dan konjungsi. Kohesi leksikal diantaranya meliputi repetisi dan, kolokasi. Hasil penelitian untuk koherensi meliputi hubungan penjumlahan, hubungan sebab-akibat, hubungan perturutan, hubungan perlawanan dan, hubungan penjelasan. Data tersebut akan dibahas dalam bagian pembahasan.

\section{Kohesi gramatikal}

a) Referensi (Penunjukkan)

Referensi ialah bagian dari kohesi gramatikal yang bersangkutan dengan pemakaian kata atau kelompok kata atau satuan gramatikal lainnya M. Ramlan (dalam Mulyana, 2005:27). Pada kontek wacana, penunjukkan referensi dibagi menjadi dua yaitu, eksoforik (di luar teks) dan endoforik anafora (di dalam teks). Referensi endoforik anafora ialah fungsi atau hal yang merujuk pada sesuatu yang telah disebutkan sebelumnya yang terdapat dalam wacana. Lihat data di bawah ini.

"Ya, alhamdulillah, semoga tugas kita lancar, biar cepat selesai dan aku bisa pulang kampung ke rumabku. Capek, jadi anak kos terus," kelub Nur. Hal itu membuat Ayu dan Widya tertawa dan langsung memeluknya.

Data di atas kata "nya" yang terdapat dalam kalimat ketiga merujuk pada kalimat pertama yaitu "Nur". Kata pada "nya" merupakan kata yang telah disebutkan pada kalimat sebelumnya yang menunjukkan bahwa kata tersebut ditujukan kepada kata "Nur".

\section{b) Substitusi (Penggantian)}

Substitusi ialah proses hasil penggantian unsur bahasa oleh unsur lain dalam satuan yang lebih besar. Penggantian dilakukan untuk memperoleh unsur pembeda atau menjelaskan struktur tertentu Harimurti Kridalaksana (dalam Mulyana, 2005:28). Lihat data di bawah ini.

Ia berharap, enam nama yang ia ajukan akan diterima dan disetujui oleh pihak kampus.

Sehingga mereka bisa melaksanakan tugas ini sebagai syarat pengerjaan skripsi mereka.

Data di atas bisa dilihat terdapat pemakaian kata "mereka" dengan fungsi sebagai pengganti yang terletak pada kalimat sebelumnya. Pengganti pada kata tersebut ditujukan kepada frasa "enam nama" yang terletak pada kalimat pertama. Enam nama yang dimaksud merupakan mahasiswa yang akan melaksanakan tugas KKN.

c) Ellipsis (Penghilangan atau Pelesapan)

Ellipsis ialah penghilangan kata yang telah disebutkan pada kata atau kalimat sebelumnya dalam satuan-satuan kebahasaan lain. Wujud atau unsur yang dihilangkan bisa 
diperkirakan bentuknya dari konteks bahasa atau konteks di luar bahasa Harimurti (dalam Mulyana, 2005:28). Lihat data di bawah ini.

"Mbah, begini..." Belum selesai Pak Prabu bicara, orang tua itu melihat wajah Widya, Ayu, lalu Wabyu, kemudian berkata, "wes, wes, ayo mlebu disek." (sudah, sudah, ayo masuk dulu).

Data di atas bisa dilihat pada kalimat pertama yang menyatakan bahwa "Mbah, begini..." ada bagian dari kata-kata tersebut yang dilesapkan atau dihilangkan. Bagian yang dihilangkan terdapat pada lambang “...”, lalu kemudian dilanjutkan dengan frasa "Belum selesai Pak Prabu bicara, orang tua itu melihat wajah Widya, Ayu, lalu Wahyu, kemudian berkata, "wes, wes, ayo mlebu disek." (sudah, sudah, ayo masuk dulu)". Dari kalimat tersebut terlihat ada sesuatu yang hendak dibicarakan tetapi tidak untuk dilanjutkan.

\section{d) Konjungsi (Kata Sambung)}

Konjungsi ialah wujud atau satuan kebahasaan yang berfungsi sebagai penyambung, perangkai atau penghubung antara kata dengan kata, frasa dengan frasa, klausa dengan klausa, kalimat dengan kalimat, dan seterusnya Harimurti (dalam Mulyana, 2005:29). Berikut beberapa jenis konjungsi yang terdapat pada novel KKN di Desa Penari.

Orang bilang, hutan ini butan paling angker di Jawa Timur. Banyak cerita yang beredar tentang pengalaman orang yang pernah melewatinya, meski hanya sebatas rumor. Namun sore ini, butan ini seakan, memiliki semacam daya tarik tersendiri.

Pada data di atas adanya kata sambung konjungsi adservatif yang ditandai dengan kata "namun". Pada kata tersebut hanya berfungsi sebagai penghubung antara kalimat pertama dan kalimat ketiga.

Wabyu, kating sekaligus teman Ayu yang satu ini memang menyebalkan sekaligus paling selengek di antara mereka. Bila saja bukan karena permintaan Ayu, lelaki kurus kering dengan mulut cerewet ini akan Widya core dari proposal anggota KKN mereka.

Pada data di atas bisa dilihat adanya kata sambung konjungsi kausal yang ditandai dengan kata "karena". Pada kata tersebut berfungsi sebagai penghubung antara kalimat pertama dan kalimat kedua.

Namun, ia harus segera membiasakan diri. Kata orang, semakin kamu tidak menyukai seseorang, maka kamu akan semakin jatuh cinta sama dia. Apalagi kalau dipikir-pikir, program KKN banyak melabirkan novel percintaan yang kadang kisabnya terjadi berdasarkan kisah nyata. 
Pada data di atas bisa dilihat adanya kata sambung konjungsi korelatif yang ditandai dengan kata "apalagi”. Pada kata tersebut hanya berfungsi sebagai penghubung antara kalimat pertama dan kalimat ke tiga.

"Ya sudah, mari saya antar. Kalau begitu kita semua sekarang kembali ke desa," ajak. Pak Prabu, tapi Bima justru menghentikannya.

Pada data di atas terdapat kata sambung konjungsi subordinatif yang ditandai dengan kata "kalau". Pada kata tersebut berfungsi sebagai penghubung antara kalimat pertama dan kalimat kedua.

"Ya sudah, nanti saya pertimbangkan, tapi saya butub laporan observasi sebelumya. Selain itu, jangan lupa kelengkapan surat dari pemerintah setempat, meliputi perangkat desa sampai jenjang terendah," jawab wanita itu kemudian.

Pada data di atas adanya kata sambung konjungsi temporal yang ditandai dengan kata "sebelumya". Pada kata tersebut hanya berfungsi sebagai penghubung antara kalimat pertama dan kalimat ke dua.

\section{Kohesi leksikal}

Kohesi leksikal ialah keterkaitan leksikal antara bagian-bagian wacana untuk memperoleh kecocokan strutur secara kohesif. Kohesi leksikal yang ditemukan ada repetisi dan kolokasi.

a) Repetisi (Pengulangan)

Repetisi ialah pengulangan kembali pada suatu unsur leksikal atau beberapa persamaan kata pada konteks pengacuan sehingga pengulangan yang terjadi mempunyai acuan yang sama. Pengulangan yang dilakukan terjadi pada pengulangan yang telah disebutkan pada kalimat sebelumnya. Lihat data di bawah ini.

Tiba-tiba kecemasannya teralibkan begitu getaran ponsel dikantong sakunya ada. Ia segera meraih ponsel untuk mengangkat panggilan seseorang yang sangat dikenalnya.

Data di atas terdapat pengulangan kembali yang telah dilakukan pada kalimat pertama dan kalimat kedua. Kalimat pertama dengan kata "ponsel" mengalami pengulangan dengan kalimat kedua yaitu kata "ponsel". Pengulangan yang dilakukan berfungsi bahwa kata yang diulang merupakan bagian penting untuk menunjukkan pentingnya kata tersebut dan memperjelas kalimat tersebut. 


\section{b) Kolokasi (Sanding Kata)}

Kolokasi ialah penanda kohesi leksikal yang berupa relasi makna leksikal yang berada pada lingkungan yang sama antara konstituen yang satu dengan konstituen yang lain. Lihat data di bawah ini.

Tidak ada yang tidak kenal dengan Ayu, gadis cantik yang selalu mejadi primadona bagi banyak lelaki di kampus. Selain dari keluarga berada, Ayu adalah sosok mahasiswi dengan segudang kegiatan organisasi yang mampu melambungkan namanya. Babkan dilingkungan kampus ia dijuluki sebagai ikon karena saking terkenal dan populernya.

Data di atas bisa dilihat terdapat hubungan kalimat pertama pada bagian kata sebelumnya dan kata sesudahnya. Kalimat pertama pada kata "cantik" berhubungan dengan kata "primadona". Kedua kata tersebut saling berhubungan dalam lingkungan yang sama untuk membantu kepaduan dalam kalimat tersebut.

\section{Koherensi dalam novel KKN Di Desa Penari}

Koherensi ialah rangkaian kalimat yang di dalamnya mengandung hubungan antara bagian kalimat yang satu dengan kalimat yang lain. Koherensi yang terdapat dalam novel ini di temukan beberapa jenis hubungan diantaranya, hubungan penjumlahan, hubungan pertuturan, hubungan perlawanan, hubungan sebab-akibat, hubungan waktu, dan hubungan penjelasan. Di bawah ini akan dipaparkan lebih jelas mengenai hubungan koherensi.

a. Hubungan Penjumlahan

Hubungan penjumlahan ialah hubungan koherensi yang mendapatkan penambahan pada sebuah karangan, penambahan tersebut berupa "dan, juga, serta". Lihat data di bawah ini.

Seminggu berselang, keputusan pibak. kampus akbirnya keluar. Widya mendapat telepon dari bu Anggi. Ia mengatakan bahwa peninjanan sudah dilakukan secara menyelurub dan dokumen yang diminta pun sudah lengkap, sehingga, pibak kampus menyetujuinya. Dengan wajab berbinar-binar, Widya segera mencari Ayu dan Nur. Mereka segera mengetabui berita besar ini.

Data di atas pada kalimat ketiga terdapat adanya penanda koherensi kata "dan”. Kata tersebut merupakan penjumlahan untuk kalimat selanjutnya. Pada kalimat ketiga yang menerangkan bahwa "Ia mengatakan bahwa peninjauan sudah dilakukan secara menyeluruh". Kemudian kalimat tersebut dilanjutkan adanya penambahan kata "dan" yang menjadikan kalimat tersebut menjelaskan bahwa "dan dokumen yang diminta pun sudah lengkap, sehingga, pihak kampus menyetujuinya. Dengan wajah berbinar-binar, Widya segera mencari Ayu dan Nur. Mereka segera mengetahui berita besar ini”. Kalimat yang lengkap terdapat pada data di atas. 


\section{b. Hubungan Perturutan}

Hubungan Perturutan ialah hubungan yang terdapat pada kalimat yang di dalamnya terbentuk karena ada kalimat yang menyatakan sebuah peristiwa, keadaan atau perbuatan yang secara terus menerus seperti diadakan atau dilakukan. berikut.

Selepas salat, gadis itu kemudian kembali ke kamar, merapikan tempat tidur, kemudian berdandan seadanya.

Data di atas frasa pertama ditemukan adanya penanda koherensi kata "kemudian". Kata itu yaitu pendanda perturutan yang menerangkan untuk frasa sebelumnya sampai frasa selanjutnya yang menjadi sebuah kalimat. Bagian frasa yang menjelaskan bahwa "Selepas salat", kemudian dilanjutkan kata "kemudian" maka berbunyi "gadis itu kemudian kembali ke kamar, merapikan tempat tidur, kemudian berdandan seadanya". Dari kalimat tersebut jika dibaca dari awal sampai akhir kaliat memiliki kalimat yang runtut.

c. Hubungan Perlawanan

Hubungan perlawanan ialah hubungan yang terbentuk karena ada kalimat yang mendapat pertentangan pada suatu perihal, perbuatan pada suatu hal yang lain, kondisi pada keadaan. Lihat data di bawah ini.

Ia mencoba mengejar ketertinggalan, meski W abyu sebenarnya tidak keberatan bila Widya mau beristirahat lebih lama lagi untuk. kesembuhannya. Namun Widya memaksa unttuk. segera mengerjakan tugasnya.

Data di atas memiliki dua kalimat. Pada kalimat pertama menjelaskan "Ia mencoba mengejar ketertinggalan, meski Wahyu sebenarnya tidak keberatan bila Widya mau beristirahat lebih lama lagi untuk kesembuhannya", pada kalimat yang kedua menjelaskan bahwa "Namun Widya memaksa untuk segera mengerjakan tugasnya". Kalimat pertama dan kedua memiliki hubungan perlawanan karena menyatakan dua hal yang bertentangan yaitu "Ia mencoba mengejar ketertinggalan, meski Wahyu sebenarnya tidak keberatan bila Widya mau beristirahat lebih lama lagi untuk kesembuhannya". Perlawanan yang ada ditandai dengan kata "Namun" di kalimat selanjutya.

\section{d. Hubungan Sebab-akibat}

Hubungan koherensi yang terjadi ketika terdapat adanya makna sebab dan makna akibat pada kalimat yang satu dengan kalimat yang lain. Misalnya kata sehingga dan sampai yang menjadi faktor penentu makna sebab dan akibat dalam kalimat. Lihat data di bawah ini.

Malam itu Pak. Prabu datang berkunjung ke penginapan mereka. Ia menjelaskan babwa mulai malam ini, Widya, Ayu, Nur, Bima, Wabyu, dan Anton akan tinggal dalam posko yang sama. Tapi kamar mereka akan terpisah oleh sekat gubuk, sehingga tidak akan ada putra-putri dalam satu ruangan yang sama . 
Data di atas ditemukan hubungan sebab-akibat yang ditandai dengan kata "sehingga". Pada kalimat yang menerangkan "Malam itu Pak Prabu datang berkunjung ke penginapan mereka. Ia menjelaskan bahwa mulai malam ini, Widya, Ayu, Nur, Bima, Wahyu, dan Anton akan tinggal dalam posko yang sama". Kalimat tersebut merupakan hubungan sebab, dan akibatnya terdapat pada kalimat selanjutnya.

e. Hubungan Penjelasan

Hubungan penjelasan ialah hubungan yang terdapat adanya kalimat yang menyatakan untuk memberikan penjelasan atau keterangan lebih lanjut pada informasi yang disampaikan, dapat dinyatakan pada kalimat selanjutnya. Lihat data di bawah ini.

\section{Perjalanan mereka cukup jauh, butuh waktu 4 bingga 6 jam. Mereka berangkat pada pukul 11 siang, dan tiba di tempat tujuan menjelang pukul 4 sore. Saat ini mereka baru akan memasuki jalanan butan yang sering dibicarakan orang.}

Data di atas mempunyai hubungan penjelasan yang menjelaskan keterangan lebih lanjut. Kalimat pertama yang menyatakan bahwa "Perjalanan mereka cukup jauh, butuh waktu 4 hingga 6 jam". Kemudian dilanjutkan pada kalimat kedua dan ketiga yang menyatakan bahwa "Mereka berangkat pada pukul 11 siang, dan tiba di tempat tujuan menjelang pukul 4 sore. Saat ini mereka baru akan memasuki jalanan hutan yang sering dibicarakan orang". Dengan demikian terdapat hubungan penjelasan yang memberikan keterangan lebih lanjut dari kalimat pertama sampai kalimat ketiga.

\section{SIMPULAN}

Berdasarkan pada hasil penelitan yang telah dilakukan dan pembahasan tentang kohesi dan koherensi dalam novel KKN Di Desa Penari, maka dapat disimpulkan Ada empat jenis kohesi gramatikal dan dua jenis kohesi leksikal. Kohesi gramatikal diantaranya: (1) Referensi atau (penunjukkan), (2) Substitusi (penggantian), (3) Elipsis (penghilangan atau pelesapan) dan, (4) Konjungsi (kata sambung). Konjungsi memiliki beberapa jenis diantaranya: konjungsi adversatif, konjungsi kausal, konjungsi korelatif, konjungsi subordinatif dan, konjungsi temporal. Kohesi leksikal diantaranya: (1) Repetisi (pengulangan) dan, (2) Kolokasi (sanding kata). Ada lima hubungan koherensi yang digunakan dalam novel KKN Di Desa Penari. Lima jenis koherensi meliputi: (1) Hubungan penjumlahan, (2) Hubungan perturutan, (3) Hubungan perlawanan, (4) Hubungan sebab-akibat dan, (5) Hubungan penjelasan.

Berdasarkan simpulan di atas memiliki beberapa saran Bagi guru bahasa Indonesia hendaknya memberi ilmu pengetahuan yang lebih tentang kohesi dan koherensi yang terdapat dalam wacana kepada peserta didiknya, pemberian yang dilakukan oleh guru supaya peserta didik menguasai penggunaan kohesi dan koherensi ketika peserta didik akan menulis suatu hal. Untuk peneliti khususnya dalam bidang bahasa Indonesia hendaknya melakukan penelitian wacana tetapi objek yang diteliti berbeda misalnya meneliti prosa, puisi, drama, 
cerpen, sehingga dapat dilihat dengan jelas perbedaan penggunaan kohesi dan koherensi yang ditemui dalam wacana itu.

\section{DAFTAR PUSTAKA}

Bahaziq, Afnan. (2016). "Cohesive Devices in Written Discurse: A Discourse Analysis of a Student's Essay Writing”. Journal Science and Education Vol. 9 No. 72016.

Djajasudarma, Fatimah. (2006). Wacana. Bandung: PT Refika Aditama.

Fatimah Siti Nor, Haris dkk. (2014). "The Use of Lexical Cohesion among TELS Post Graduate Student in Academic Writing". Journal of Education and Human Development Vol. 3 No. 22014.

Guntur Tarigan, Heny. (2009). Pengajaran Wacana. Edisi Revisi. Bandung: Angkasa.

Hanifah, Wardah. (2014). "Analisis Kohesi dan Koherensi pada Wacana Buletin Jumat". Jurnal Bahasa Vol. 11 No. 22014.

Hermaji, Bowo. (2016). Teori dan Metode Sosiolinguistik. Yogyakarta: Magnum Pustaka Utama.

Kesuma, Tri Mastoyo Jati. (2007). Pengantar (Metode) Penelitian Bahasa. Yogyakarta: Carasvatibooks.

Muhyidin, Asep. (2018). "Kohesi Gramatikal Konjungsi dalam Karya Sastra dan Implikasinya bagi Pembelajaran Bahasa Indonesia di SMA". Jurnal kebahasaan, Kesusastraan, dan Budaya Vol. 8 No. 22018.

Mulyana. (2005). Kajian Wacana. Yogyakarta: Tiara Wacana.

Nurfitriani, Bahri Rajab dkk. (2018). "Analisis Kohesi Dan Koherensi Dalam Proposal Mahasiswa Pbsi Tanggal 23 Desember 2014”. Jurnal Bahasa dan Sastra Vol. 12 No. 12018.

Simpleman. 2019. KKN di Desa Penari. Jakarta. Bukune. 